Tropical Journal of Pharmaceutical Research March 2017; 16 (3): 723-733

ISSN: $1596-5996$ (print); 1596-9827 (electronic)

(C) Pharmacotherapy Group, Faculty of Pharmacy, University of Benin, Benin City, 300001 Nigeria.

All rights reserved.

Available online at http://www.tjpr.org

Review Article

http://dx.doi.org/10.4314/tjpr.v16i3.30

\title{
Recent advancements in oxadiazole-based anticancer agents
}

\author{
Irfan Rasool ${ }^{1}$, Matloob Ahmad ${ }^{1 *}$, Zulfiqar Ali Khan ${ }^{1}$, Asim Mansha ${ }^{1}$, Tahir \\ Maqbool $^{1}$, Ameer Fawad Zahoor ${ }^{1}$ and Sana Aslam ${ }^{2 *}$ \\ ${ }^{1}$ Department of Chemistry, Government College University, Faisalabad-38000, Pakistan, ${ }^{2}$ Department of Chemistry, \\ Government College Women University, Faisalabad-38000, Pakistan
}

*For correspondence: Email: Matloob.Ahmad@gcuf.edu.pk, matloob_123@yahoo.com, sana_gy@yahoo.com; Tel: 0092-412649975

Received: 19 August 2016

Revised accepted: 6 February 2017

\begin{abstract}
Oxadiazole ring system occupies a significant position among heterocyclic templates for medicinal compounds due to its wide spectrum of biological activities. This article entails an in-depth review of the ability of oxadiazole derivatives to induce apoptosis of cancer cells. FDA has approved a number of drugs for the treatment of different types of cancer. There is, however, a continuing need for the development of new anticancer agents due to increasing cases of drug resistance. Moreover, medicinal chemists are continuously struggling to invent selective cytotoxic agents with minimum side effects. This work reviews the significance of oxadiazole ring system and its potential to act as a template for novel anticancer agents.
\end{abstract}

Keywords: Oxadiazole ring system, Anticancer activity, Antitumor activity, Cytotoxicity, Apoptosis

Tropical Journal of Pharmaceutical Research is indexed by Science Citation Index (SciSearch), Scopus, International Pharmaceutical Abstract, Chemical Abstracts, Embase, Index Copernicus, EBSCO, African Index Medicus, JournalSeek, Journal Citation Reports/Science Edition, Directory of Open Access Journals (DOAJ), African Journal Online, Bioline International, Open-J-Gate and Pharmacy Abstracts

\section{INTRODUCTION}

Cancer is a continued threat for humanity on the globe both in advanced countries as well as developing ones. Various anticancer drugs have been approved by FDA for the treatment of different types of cancers. Most of them are structurally based upon heterocyclic ring systems. Oxadiazole ring system is at significant position among heterocycles due its medicinal properties. This ring system exists in the form of structural isomers 1,3,4-oxadiazole, 1,2,4oxadiazole and 1,2,3-oxadiazole.

\section{1,3,4-Oxadiazole}

1,3,4-Oxadiazole derivatives are frequently reported for their anticancer activity. A series of 1-[\{(5-Alkenyl/hydroxyalkenylsubstituted)-1,3,4-
oxadiazol-2-yl\}-methyl]-2-methyl-1Hbenzimidazoles has been recently reported as anticancer agents. Among them, compounds 1, 2 \& 3 showed moderate to weak activity against Hep3B (human hepatocellular carcinoma), HeLa (human cervical carcinoma) and MCF 7 (human breast adenocarcinoma) cell lines (Table 1) [1]. A series of indole and 1,3,4-oxadiazole hybrid compounds were recently prepared by Hatti and coworkers and were screened against MCF-7, $\mathrm{KB}$, Colo-205, and A-549 cancer cell lines. Among them, compounds 4-8 were found to exhibit significantly higher anticancer activity as compared to the reference drug etoposide (Table 2) [2]. Rashid et al prepared 3-((5-)(3-(1Hbenzo[d] imidazol-2-yl)-3-oxopropyl)-1,3,4-oxadiazol-2-yl)methyl)-5-methylpyrimidine-2,4 $(1 H, 3 H)$ dione (9) which exhibited significant 
antiproliferative activity with $\mathrm{GI}_{50}$ value of 0.09 $\mu \mathrm{M}[3]$.

Yonova et al reported 2-phenyl-5-(phenylthio)1,3,4-oxadiazole (10) as selective anticancer agent against the MCF-7 with $\mathrm{EC}_{50}$ value of 7.9 $\mu \mathrm{M}$ [4]. Valente et al described the synthesis of hydroxamates and 2-aminoanilides having 1,3,4oxadiazole moiety as histone deacetylase inhibitors. Among the series of naphthalene based oxadazoles, compounds 11 and 12 appeared as the most potent and selective compounds against HDAC1. Compound 11 was more effective against U937 leukemia cells with $\mathrm{IC}_{50}$ value of $7.8 \mu \mathrm{M}$ than reference drug (SAHA) and compound 12 displayed cell di $\square$ erentiation comparable to reference, MS-275 [5]. Kumar et al synthesized oxadiazole containing sulfonamides 13 and 14 which were weakly active against K562, Colo-205, MDA-MB231 and IMR-32 cancer cell lines as shown in the Table $\mathbf{3}$ [6].<smiles>[R]c1nnc(Cn2c(C)nc3ccccc32)o1</smiles>

(1-3)

Where

$1 ; R=\gtrsim H_{7}$

2; $\mathrm{R}=\mathrm{H}_{3} \mathrm{C}=\mathrm{H}$

3; $\mathrm{R}=$<smiles>C=CC(O)CCC=CCCCC</smiles><smiles>COc1cc(-c2nnc(COc3ccc(C(c4cn(C)c5ccccc45)c4cn(C)c5ccccc45)cc3)o2)cc(OC)c1OC</smiles>

(4)<smiles>COc1ccc(-c2nnc(COc3ccc(C(c4cn(C)c5ccccc45)c4cn(C)c5ccccc45)cc3)o2)cc1</smiles>

(5)<smiles>CC=CCCCCCOc1ccc(C(c2cn(C)c3ccccc23)c2cn(C)c3ccccc23)cc1</smiles>

(6)<smiles>Cc1c[nH]c(=O)n(Cc2nnc(CCC(=O)c3nc4ccccc4[nH]3)o2)c1=O</smiles>

(7)

(8)

(9)<smiles>c1ccc(Sc2nnc(-c3ccccc3)o2)cc1</smiles>

(10)<smiles>O=C(/C=C/c1ccc(Cc2nnc(Cc3cccc4ccccc34)o2)cc1)NO</smiles>

(11)<smiles>Nc1ccccc1NC(=O)c1ccc(Cc2nnc(Cc3cccc4ccccc34)o2)cc1</smiles>

(12)

Figure 1: Structures of 1,3,4-Oxadiazoles (1-12) exhibiting potent anticancer activity

Table 1: $\mathrm{IC}_{50}(\mu \mathrm{M})$ values of compounds $\mathbf{1}$ - $\mathbf{3}$ against various cancer cell lines

\begin{tabular}{lcccc}
\hline Compound & Hep3 B & MCF 7 & HeLa & PBMC \\
\hline $\mathbf{1}$ & $11.10 \pm 1.1$ & $12.40 \pm 0.5$ & $11.70 \pm 2.9$ & $42.42 \pm 1.2$ \\
$\mathbf{2}$ & $14.10 \pm 0.8$ & $12.20 \pm 0.7$ & $14.40 \pm 1.2$ & $41.27 \pm 1.8$ \\
$\mathbf{3}$ & $13.90 \pm 0.8$ & $11.10 \pm 0.7$ & $10.60 \pm 1.2$ & $43.28 \pm 1.8$ \\
Doxo & $02.35 \pm 1.2$ & $03.12 \pm 1.7$ & $03.56 \pm 2.7$ & $09.23 \pm 2.6$ \\
5-Fu & $03.45 \pm 2.1$ & $04.12 \pm 2.3$ & $02.78 \pm 2.6$ & $08.91 \pm 1.9$ \\
\hline
\end{tabular}


Table 2: Cytotoxic activity $\left(\mathrm{GI}_{50} / \mu \mathrm{M}\right)$ of compounds 4 - 8

\begin{tabular}{lcccc}
\hline Compound & Breast MCF-7 & Oral KB & Colon Colo-205 & Lung A-549 \\
\hline $\mathbf{4}$ & $<0.1$ & $<0.1$ & 1.3 & $<0.1$ \\
$\mathbf{5}$ & 0.12 & - & 0.13 & $<0.1$ \\
$\mathbf{6}$ & 0.14 & $<0.1$ & $<0.1$ & $<0.1$ \\
$\mathbf{7}$ & $<0.1$ & 0.11 & - & $<0.1$ \\
$\mathbf{8}$ & $<0.1$ & 0.18 & 0.15 & $<0.1$ \\
Etoposide & 2.11 & 0.31 & 0.13 & 3.08 \\
\hline
\end{tabular}

Table 3: Anti-proliferative activity (\% cell survival) of compounds 13 and 14 (10 $\mu \mathrm{M})$

\begin{tabular}{lcccc}
\hline Compound & K562 & Colo-205 & MDA-MB 231 & IMR-32 \\
\hline $\mathbf{1 3}$ & 59.31 & 64.00 & 62.40 & 68.22 \\
$\mathbf{1 4}$ & 48.20 & 61.70 & 60.05 & 60.81 \\
Control (0.1 \% DMSO) & 100 & 100 & 100 & 100 \\
\hline
\end{tabular}

Zhang et al reported the synthesis of structural hybrids of 1,3,4-oxadiazole and 1,3,4-thiadiazole heterocycles having schiff base side chain. Among these compounds, compound 15 exhibited growth inhibition of SMMC-7721 cells with $\mathrm{IC}_{50}$ value of $2.84 \mu \mathrm{M}$. Compounds 16 and 17 displayed antitumor activity with $\mathrm{IC}_{50}$ values of 4.56 and $4.25 \mu \mathrm{M}$, respectively against MCF-7 cells. Compounds 17 and 18 exhibited significant anti-proliferative activity against A549 cells, with $\mathrm{IC}_{50}$ values of 4.13 and $4.11 \mu \mathrm{M}$, respectively [7].<smiles>O=[N+](NCc1nnc(-c2ccc(F)cc2)o1)c1ccc(C(F)(F)F)cc1</smiles>

(13)<smiles>Oc1ccccc1/C=N\c1nnc(SCc2nnc(-c3ccc(Cl)cc3)o2)s1</smiles><smiles>O=[N+]([O-])c1ccc(-c2nnc(CSc3nnc(/N=C\c4ccccc4O)s3)o2)cc1</smiles><smiles>Fc1ccccc1NCn1nc(-c2ccc3ccccc3n2)oc1=S</smiles>

(19)<smiles>O=C(Cc1nnc(SCCCN2CCN(c3nc4ccccc4o3)CC2)o1)Nc1ccccc1</smiles>

(21)
Quinoline substituted 1,3,4-oxadiazoles are reported for their inhibitory potential against HepG2, SGC-7901 and MCF-7 cell lines. Among the series, compounds 19 and 20 showed the best activity among the series and the results were comparable to the control as shown in table 4 [8]. Murty et al coupled piperazine substituted benzothiazole/benzoxazole with 1,3,4oxadiazole-2-thiol to get corresponding structural hybrids 21 and 22 which displayed excellent cytotoxic activity as shown in the Table 5 [9].<smiles></smiles>

(14)<smiles>COc1ccc(-c2nnc(CSc3nnc(/N=C\c4ccccc4O)s3)o2)cc1</smiles><smiles>Oc1ccccc1/C=N\c1nnc(SCc2nnc(-c3ccccc3)o2)s1</smiles><smiles>S=c1oc(-c2ccc3ccccc3n2)nn1CNc1ccc(Cl)cc1</smiles>

(20)<smiles>O=C(Cc1nnc(SCCCN2CCN(c3nc4ccccc4s3)CC2)o1)Nc1ccccc1</smiles>

(22)

Figure 2: Structures of 1,3,4-Oxadiazoles (13-22) exhibiting potent anticancer activity 
1,3,4-Oxadiazoles derivatives (23 and 24) exhibited good activity with $\mathrm{IC}_{50}$ values of $16 \mu \mathrm{M}$ and $10 \mu \mathrm{M}$ respectively against K562 cancer cell line [10]. Shamsuzzaman et al synthesized 25 that exhibited moderate anticancer behavior against human leukemia cell line (HL-60) $\left(\mathrm{IC}_{50}\right.$ $=17.33)$ [11].

Bondock et al synthesized heterocyclic 1,3,4oxadiazole derivatives derivatives (25-30) that displayed promising in-vitro antitumor activity as shown in the Table 6 [12]. Feng et al synthesized a series of thio-substituted 1,3,4-oxadiazole derivatives (31 \& 32) and screened them against human leukemia tumor cell line (K-562). Compounds $\mathbf{3 1}$ and $\mathbf{3 2}$ were docked into the ATPase domain of TP-II and docking scores are shown in the Table 7 [13].<smiles>O=C(c1ccc(F)cc1)c1cc(F)c(OCc2nnc(COc3c(F)cc(C(=O)c4ccc(Cl)cc4)cc3Cl)o2)c(Cl)c1</smiles>

(23)

(24)

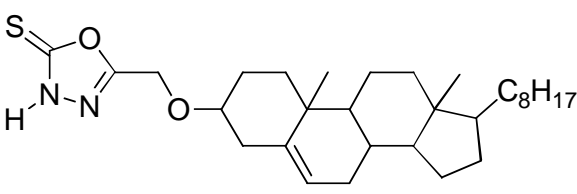

(25)<smiles>Nc1n[nH]c(Nc2ccccc2)c1-c1nnc(NC(=O)c2ccccc2)o1</smiles>

(28)<smiles>N#CCc1nnc(NC(=O)c2ccccc2)o1</smiles>

(26)<smiles>CC1=CSC(=C(C#N)c2nnc(NC(=O)c3ccccc3)o2)N1c1ccccc1</smiles><smiles>O=C1OC2C=CC=CC2C=C1c1nnc(NC(=O)c2ccccc2)o1</smiles>

$\operatorname{Ar}=1,3-d i p h e n y \mid p y r a z o l-4-y l$

(29)

(30)<smiles>CC(NC(=O)c1ccc(Cl)cc1)c1n[nH]c(=S)o1</smiles>

(31)<smiles>Nc1cc(Br)c(-c2nnc(CCC(=O)c3nc4ccccc4[nH]3)o2)c(Br)c1</smiles>

(34)<smiles>O=C1Nc2ccc(Cl)cc2/C1=N/c1ccc(-c2nnc(S)o2)cc1</smiles>

(37)<smiles>CC(C)C(NC(=O)c1ccc([N+](=O)[O-])cc1)c1n[nH]c(=S)o1</smiles>

(32)<smiles>O=C(CCc1nnc(-c2ccc(Cl)cc2Cl)o1)c1nc2ccccc2[nH]1</smiles>

(33)<smiles>O=C1Nc2ccc(F)cc2C1=Nc1ccc(-c2nnc(S)o2)cc1</smiles>

(35)

(36)<smiles>O=C1Nc2ccc(Br)cc2C1=Nc1ccc(-c2nnc(S)o2)cc1</smiles>

(38)

Figure 3: Structures of 1,3,4-Oxadiazoles (23-38) exhibiting potent anticancer activity 
Table 4: Anticancer activities ( $\left.\mathrm{IC}_{50}, \mu \mathrm{M}\right)$ of compounds 19 and 20

\begin{tabular}{|c|c|c|c|}
\hline Compound & HepG2 & SGC-7901 & MCF-7 \\
\hline 19 & $1.2 \pm 0.2$ & $8.3 \pm 1.6$ & $6.8 \pm 0.5$ \\
\hline 20 & $0.8 \pm 0.2$ & $7.6 \pm 1.0$ & $7.1 \pm 0.8$ \\
\hline
\end{tabular}

Table 5: Cytotoxic activity $\left(\mathrm{IC}_{50}, \mu \mathrm{M}\right)$ of compounds 21 and 22

\begin{tabular}{lccccc}
\hline Compound & MCF 7 & HeLa & A431 & HepG2 & A549 \\
\hline $\mathbf{2 1}$ & 52.7 & 63.9 & 36.9 & 88.9 & 102.0 \\
$\mathbf{2 2}$ & 39.0 & 78.1 & 55.9 & 325.1 & 88.7 \\
Curcumin & 26.0 & 17.0 & 22.0 & 16.0 & 22.0 \\
\hline
\end{tabular}

Table 6: Cytotoxicity values [ $\left.\mathrm{IC}_{50}(\mu \mathrm{g} / \mathrm{ml})\right]$ of compounds $26-30$

\begin{tabular}{lcccc}
\hline Compound & HepG2 & WI-38 & VERO & MCF-7 \\
\hline $\mathbf{2 6}$ & 21.2 & 24.4 & 30.3 & 39.2 \\
$\mathbf{2 7}$ & 12.4 & 17.3 & 15.8 & 25.8 \\
$\mathbf{2 8}$ & 33.7 & 38.4 & 36.3 & 38.3 \\
$\mathbf{2 9}$ & 38.1 & 24.1 & 39.6 & 37.4 \\
$\mathbf{3 0}$ & 35.6 & 35.8 & 34.5 & 32.6 \\
$\mathbf{5 - F u}$ & 8.6 & 3.2 & 6.5 & 2.3 \\
\hline
\end{tabular}

Table 7: Docking score and $\mathrm{IC}_{50}$ values for compounds 31 and 32

\begin{tabular}{lccc}
\hline Compound & Glide $\{$ TP-II (PDB: & Glide $\left\{\begin{array}{c}\text { Tubulin }(\text { PDB: } \\
\text { 1SA0) }\end{array}\right.$ & K562 $\left[\right.$ IIC $\left._{50}(\boldsymbol{\mu M})\right]$ \\
\hline $\mathbf{3 1}$ & $>-5$ & $>-5$ & 31.14 \\
$\mathbf{3 2}$ & -6.87 & $>-5$ & 43.55 \\
Hydroxy-urea (standard & - & - & 687.94 \\
drug) & & & \\
\hline
\end{tabular}

Benzimidazole and oxadiazole hybrids were synthesized by Rashid et al. Amongst them, compound 33 emerged as the most significant anticancer agent against various cancer cell lines [14]. Husain et al also synthesized benzimidazole and oxadiazole hybrids. Among them, compound 34 exhibited significant growth inhibition [15]. Fadda et al synthesized a new series of quinoline based oxadiazoles. The compound $\mathbf{3 5}$ showed a strong cytotoxicity as shown in the Table 8 [16].

Gudipati et al synthesized a series of indole containing oxadiazoles. The compounds produced a dose dependent inhibition of the growth of HeLa cancer cell line. The $\mathrm{IC}_{50}$ values were found between 10.64 and $33.62 \mu \mathrm{M}$. The compounds 36, $37 \& 38$ exhibited anticancer activity comparable to Cisplatin (Table 9) [17].

Dash et al synthesized the series of 3,5-disubstituted 1,3,4-oxa-diazole-2-thione derivatives. Among the synthesized compounds, the compounds 39, 40, 41, $42 \& 43$ were found more active than 5-FU as shown in Table 10 [18]. Zhang et al synthesized 1,4-benzodioxane based 1,3,4-oxadiazoles as potential telomerase inhibitors. Compounds 44, 45, 46, 47 and 48 were observed as potent anticancer compounds with $\mathrm{IC}_{50}$ concentration range from 7.21 $\mu \mathrm{M}$ to 25.87 $\mu \mathrm{M}$ against HEPG2, SW1116, HELA and BGC823 [19].

Abu-Zaied et al synthesized novel thioglycosides having 1,3,4-oxadiazole moiety. The pharmacological evaluation of compounds 49, 50 and 51 was carried out and the compounds were found to be effective against MCF-7 (breast) and HEPG2 (liver) cells. The $\mathrm{IC}_{50}$ values were found in the range of 2.67-20.25 $(\mu \mathrm{g} / \mathrm{mL})$ for MCF-7 (breast cancer cell line) and 4.62-43.6 $(\mu \mathrm{g} / \mathrm{mL})$ for HEPG2 (liver cancer cell line) [20].

5-(3-Indolyl)-2-(substituted)-1,3,4-oxadiazoles were screened for human cancer cell lines and among the compounds, compounds 52, 53 and 54 exhibited potent cytotoxicity $\left(\mathrm{IC}_{50^{\sim 1}} \mu \mathrm{M}\right)$ and selectivity against human cancer cell lines as shown in Table 11 [21]. Tong et al. described the synthesis of compound 55 showed the best activity with $\mathrm{EC}_{50}$ value of $3.7 \mu \mathrm{M}$ [22]. Oxadiazole compounds 56 and 57 were appeared as potent members of anticancer family of drugs [23]. 


\section{1,2,4-Oxadiazole}

There are sufficient number of evidence dealing with anticancer behavious of 1,2,4-oxadiazole derivatives. ejrimidin-3-yl)-3-(piperazin-1-ylmethyl)-1,2,4oxadiazole based carboxamides, sulfonamides, ureas, and thioureas are recently reported for<smiles>O=[N+]([O-])c1ccc(-c2nn(CNc3ccccn3)c(=S)o2)cc1</smiles>

(39)<smiles>O=[N+]([O-])c1ccc(-c2nn(CNc3ccccc3)c(=S)o2)cc1</smiles>

(40)<smiles>S=c1oc(-c2ccc(Cl)cc2Cl)nn1CNc1ccccn1</smiles>

(41)<smiles>Oc1ccc(-c2nn(CNc3ccccn3)c(=S)o2)cc1</smiles><smiles>Cc1ccc(-c2nn(CNc3ccccn3)c(=S)o2)cc1</smiles>

(43)<smiles>COc1ccccc1CSc1nnc(-c2ccc3c(c2)OCCO3)o1</smiles>

(44)<smiles>CC(C)(C)[Mg]SCc1ccccc1Br</smiles>

(45)<smiles>Brc1cccc(CSc2nnc(-c3ccc4c(c3)OCCO4)o2)c1</smiles>

(46)<smiles>Ic1ccccc1CSc1nnc(-c2ccc3c(c2)OCCO3)o1</smiles><smiles>CC(C)Cc1nn(-c2ccccc2)cc1-c1nnc(S)o1</smiles>

(49)<smiles>Brc1cccc(CSc2nnc(-c3ccc4c(c3)OCCO4)o2)c1</smiles>

(47)

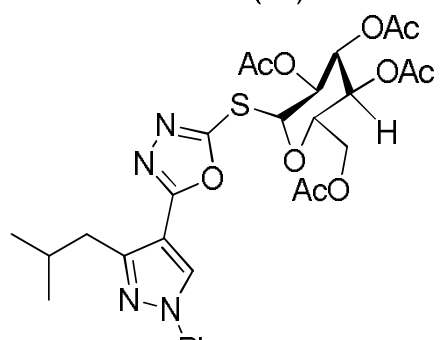

(50)<smiles>C/C=C\Cc1c[nH]cc1-c1nnc(-c2c[nH]c3ccccc23)o1</smiles>

$\mathrm{Ph}$

(51)<smiles>NC(=O)c1cccc2[nH]c(-c3ccc(-c4nnco4)cc3)nc12</smiles>

(55)

(52)<smiles>Oc1ccccc1-c1nn(CNc2cccc(Cl)c2)c(=S)o1</smiles>

(56)<smiles>Oc1ccccc1-c1nn(CNc2ccc(Cl)cc2)c(=S)o1</smiles>

(57)

Figure 4: Structures of anticancer 1,3,4-Oxadiazoles (39-57) 
Table 8: Cytotoxicity of the Synthesized Compound $35\left(\mathrm{IC}_{50}, \mu \mathrm{g} / \mathrm{ml}\right)$

\begin{tabular}{lcccc}
\hline Compound & HepG2 & Wl-38 & VERO & MCF-7 \\
\hline 35 & 22.4 & 27.3 & 25.8 & 40.8 \\
5-Fluorouracil & 8.6 & 3.2 & 6.5 & 2.3 \\
\hline \multicolumn{2}{c}{ Table 9: Cytotoxicity of the Synthesized Compounds $\mathbf{3 6 - 3 8}\left(\mathrm{IC}_{50}, \boldsymbol{\mu g} / \mathrm{ml}\right)$}
\end{tabular}

\begin{tabular}{lccc}
\hline Compound & IC $_{50}(\boldsymbol{\mu M}$, HeLa $)$ & IC $_{50}(\boldsymbol{\mu M}, \mathbf{I M R}-\mathbf{3 2})$ & IC $_{50}(\boldsymbol{\mu M}, \mathbf{M C F}-7)$ \\
\hline $\mathbf{3 6}$ & 11.99 & 13.48 & 15.57 \\
$\mathbf{3 7}$ & 12.84 & 15.84 & 16.68 \\
$\mathbf{3 8}$ & 10.64 & 12.68 & 16.06 \\
Cisplatin & 14.08 & 13.64 & 13.54 \\
\hline
\end{tabular}

Table 10: Anticancer activity of oxadiazole derivatives against EAC bearing mice

\begin{tabular}{|c|c|c|}
\hline Compound & RBC (106 cells) & WBC (103 cells) \\
\hline Normal saline & $11.04 \pm 0.33$ & $4.47 \pm 0.15$ \\
\hline Induce control & $2.77 \pm 0.13$ & $10.31 \pm 0.23$ \\
\hline 39 & $3.57 \pm 0.20^{\star}$ & $7.73 \pm 0.21^{* * *}$ \\
\hline 40 & $5.68 \pm 0.30^{* * *}$ & $5.57 \pm 0.14^{* * *}$ \\
\hline 41 & $7.23 \pm 0.07^{\star \star \star}$ & $4.47 \pm 0.12^{\star \star \star}$ \\
\hline 42 & $6.25 \pm 0.16^{\star * *}$ & $4.97 \pm 0.10^{\star * *}$ \\
\hline 43 & $8.27 \pm 0.16^{\star \star \star}$ & $4.62 \pm 0.14^{\star \star \star}$ \\
\hline 5-Fluorouracil & $8.32 \pm 0.15^{\star * *}$ & $4.81 \pm 0.14^{\star * *}$ \\
\hline
\end{tabular}

Table 11: Cytotoxicity (IC $50, \mu \mathrm{M})$ of 5-(3-indolyl)-2-(substituted)-1,3,4-oxadiazoles (52 - 54)

\begin{tabular}{lcccccc}
\hline Compound & PC3 & DU145 & LnCaP & MDA-MB-231 & MCF7 & PaCa2 \\
\hline $\mathbf{5 2}$ & 4.1 & 20.4 & 10.0 & $>10^{3}$ & 1.0 & 1.6 \\
$\mathbf{5 3}$ & 710.8 & 170 & 69.4 & $>10^{3}$ & 5.4 & 0.9 \\
$\mathbf{5 4}$ & $>10^{3}$ & $>10^{3}$ & $>10^{3}$ & $>10^{3}$ & 35.2 & 1.4 \\
\hline
\end{tabular}

their effective activity against HeLa cells. Five compounds 58-62 exhibited activity with $\mathrm{IC}_{50}$ value $<10 \mu \mathrm{g} / \mathrm{cm}^{3}$ which was greater than reference drug, paclitaxel with $I_{50}$ value 30 $\mu \mathrm{g} / \mathrm{cm}^{3}$ [24]. Miralinaghi et al described the synthesis of triaryl-1,2,4-oxadiazole derivatives and screened them for anti-proliferative activities against MCF7 and K562 cell lines using MTT assay. Out of these, compound 63 showed remarkable activity against MCF7 and K562 cell lines with $\mathrm{IC}_{50}$ values of 6.50 and $21.66 \mu \mathrm{M}$, respectively [25].

Tsygankova and Zhenodarova reported a series of 3,5-Diaryl-1,2,4-oxadiazoles derivatives. Five compounds (64-68) were found more active against antitumor agents as shown in the table 12 [26]. 1,2,4-Oxadiazole (69) exhibited effective activity against DU145 $\left(\mathrm{IC}_{50}: 9.3 \mu \mathrm{M}\right)$ cell lines [27].

Previously, Yang et al synthesized the series of Oxadiazole derivatives as inhibitors of human leukemia HL-60 cells. Compound 70 was one of the potent anti-proliferative agent without inhibition of GST P1-1 activity. Compounds 71 and 72 exhibited antitumor activity with $\mathrm{IC}_{50}$ value less than $5 \mu \mathrm{M}$ as shown in the table 13 [28]. Kemnitzer et al synthesized a new series of 3aryl-5-aryl-1,2,4-oxadiazoles. Compound 73 was found more active against T47D cancer cell growth with $\mathrm{GI}_{50}$ value of $0.13 \mu \mathrm{M}$ [29]. Kumar et al synthesized a series of 3,5-disubstituted-1,2,4oxadiazoles. Compound 74 appeared as the most selective ( $>450$-fold) whereas 75 as the most potent compound having $\mathrm{IC}_{50}$ value of 10 $\mathrm{nM}$ against prostate cancer cell lines (Table 14) [30].

Thiophene containing 1,2,4-oxadiazole (76) has been found as good anticancer compound against several breast and colorectal cancer cell lines as reported by Zhang et al. Moreover, compound 77 has been found to have in vivo activity in a MX-1 tumor model as shown in the Table 15 [31].

\section{1,2,3-Oxadiazole}

In contrast to other oxadiazoles, 1,2,3-oxadiazole ring system is unstable. It isomerizes to formyldiazomethane [32, 33]. That's why, it is least studied for its biological activities. 
<smiles>Cc1cc(C)n2ncc(-c3nc(CN4CCN(C(=O)Nc5ccc(OC(F)(F)F)cc5)CC4)no3)c2n1</smiles>

(58)<smiles>Cc1cc(C)n2ncc(-c3nc(CN4CCN(C(=O)c5ccc(Cl)c(Cl)c5)CC4)no3)c2n1</smiles>

(60)<smiles>Cc1cc(I)n2ncc(-c3nc(C)no3)c2n1</smiles>

(61)<smiles>Cc1cc(C)n2ncc(-c3nc(CN4CCN(C(=O)Nc5ccc(Cl)c(Cl)c5)CC4)no3)c2n1</smiles>

(59)<smiles>Fc1ccc(C2ON=C(c3ccc(Cl)cc3)N2c2ccccc2)cc1</smiles>

(63)<smiles>FC(F)(F)c1ccc(-c2noc(-c3occc3Cl)n2)cn1</smiles>

(64)<smiles>FC(F)(F)c1cccc(-c2noc(-c3occc3Cl)n2)c1</smiles>

(65)<smiles>Cc1cc(CI)ncc1-c1noc(-c2occc2Br)n1</smiles>

(66)<smiles>FC(F)(F)c1ccc(-c2noc(-c3occc3Br)n2)cn1</smiles>

(67)<smiles>FC(F)(F)c1cncc(-c2noc(-c3occc3Br)n2)c1</smiles>

(68)<smiles>CCCCCOc1cc(-c2noc(C3CCN(C(=O)OC(C)(C)C)CC3)n2)ccc1OC</smiles>

(69)

Figure 5: 1,2,4-Oxadiazoles (55-69) exhibiting potent anticancer activity<smiles>C=C(CC)C(=O)c1ccc(OCC)c(Cl)c1Cl</smiles>

(73)<smiles>COc1ccc(-c2noc(C3CCCN3)n2)cc1OC1CCCC1</smiles>

(74)<smiles>COc1ccc(-c2noc(C3CCNCC3)n2)cc1OC1CCCC1</smiles>

(75)<smiles>FC(F)(F)c1ccc(-c2noc(-c3sccc3Cl)n2)cc1</smiles>

(76)<smiles>Clc1ccc(-c2noc(-c3sccc3Cl)n2)cn1</smiles>

(77)

Figure 6: 1,2,4-Oxadiazoles (70-77) exhibiting potent anticancer activity 
Table 12: 3-Aryl-5-aryl-1,2,4-oxadiazoles (64-68) as anticancer agents

\begin{tabular}{lc}
\hline Compound & $\mathrm{EC}_{50}(\mu \mathrm{M})$ \\
\hline $\mathbf{6 4}$ & 0.36 \\
65 & 1.33 \\
66 & 1.21 \\
$\mathbf{6 7}$ & 0.55 \\
$\mathbf{6 8}$ & 0.55 \\
\hline
\end{tabular}

Table 13: Growth inhibition of GST P1-1 and HL-60 cells by compounds $\mathbf{7 0 - 7 2}$

\begin{tabular}{lcc}
\hline Compound & $\begin{array}{c}\mathrm{IC}_{50}(\mu \mathrm{M}) \text { for } \\
\text { inhibiting } \\
\text { GST P1-1 } \\
\text { activity }\end{array}$ & $\begin{array}{c}\mathrm{GI}_{50}(\mu \mathrm{M}) \text { for } \\
\text { inhibiting HL } \\
\mathbf{6 0} \text { cell growth }\end{array}$ \\
\hline $\mathbf{7 0}$ & $>40$ & $1.1 \pm 0.2$ \\
$\mathbf{7 1}$ & $4.0 \pm 0.3$ & $2.3 \pm 0.2$ \\
$\mathbf{7 2}$ & $3.6 \pm 0.7$ & $1.7 \pm 0.1$ \\
\hline
\end{tabular}

Table 14: Cytotoxicity profile of 3,5-disubstituted-1,2,4-oxadiazoles $\left(\mathrm{IC}_{50}(\mu \mathrm{M})\right.$

\begin{tabular}{cccccccc}
\hline Compounds & PC3 & DU145 & LnCaP & MCF7 & MDA231 & HCT116 & PaCa2 \\
\hline 74 & $>10^{3}$ & $242 \pm 0.1$ & $0.043 \pm 0.04$ & $>10^{3}$ & $212.2 \pm 0.3$ & $184.8 \pm 0.1$ & $19.49 \pm 0.08$ \\
75 & $>10^{3}$ & $0.057 \pm 0.07$ & $0.010 \pm 0.02$ & $3.88 \pm 0.3$ & $0.37 \pm 0.08$ & $1.54 \pm 0.03$ & $0.54 \pm 0.03$ \\
\hline
\end{tabular}

Table 15: Cell Growth Inhibition Activity of 3-Aryl-5aryl-1,2,4-oxadiazoles $\left(\mathrm{Gl}_{50}, \mu \mathrm{M}\right)$

\begin{tabular}{cccc}
\hline Compounds & T47D & DLD1 & H1299 \\
\hline 76 & $0.22 \pm 0.05$ & $0.77 \pm 0.29$ & $>10$ \\
77 & $0.20 \pm 0.02$ & $0.80 \pm 0.11$ & $>10$ \\
\hline
\end{tabular}

\section{CONCLUSION}

We have summed up recent literature dealing with anticancer behavior of oxadiazole ring system. Keeping in view the focus of article, we have mentioned only the potent anticancer compounds of the family. The data presented in this article is collected from recent publications in well reputed international journals of medicinal and pharmaceutical chemistry. The structural features could be interesting for medicinal chemists in devising anticancer drugs.

\section{DECLARATIONS}

\section{Acknowledgement}

The authors are grateful to 'Higher Education Commission of Pakistan' for funding the research through project No. 20-3715/NRPU/R\&D/HEC/14 $/ 162$ and Government College University, Faisalabad for providing free access to full text articles.

\section{Conflict of Interest}

No conflict of interest associated with this work.

\section{Contribution of Authors}

The authors declare that this work was done by the authors named in this article and all liabilities pertaining to claims relating to the content of this article will be borne by them.

\section{Open Access}

This is an Open Access article that uses a funding model which does not charge readers or their institutions for access and distributed under the terms of the Creative Commons Attribution License (http://creativecommons.org/licenses/by 14.0) and the Budapest Open Access Initiative (http://www.budapestopenaccessinitiative.org/rea d), which permit unrestricted use, distribution, and reproduction in any medium, provided the original work is properly credited.

\section{REFERENCES}

1. Varshney $H$, Ahmad $A$, Rauf $A$, Sherwani $A$, Owais $M$. Multistep synthesis of 1-[\{(5-alkenyl/hydroxyl alkenylsubstituted)-1,3,4-oxadiazol-2-yl\}-methyl]-2methyl-1H-benzimidazole series and in vitro anticancer screening, SAR studies. Med Chem Res 2015; 24: 944953.

2. Hatti I, Sreenivasulu R, Jadav SS, Ahsan MJ, Raju RR. Synthesis and biological evaluation of 1,3,4-oxadiazolelinked bisindole derivatives as anticancer agents. Monatsh Chem 2015; 146: 1699-1705.

3. Rashid M, Husain A, Mishra R, Karim S, Khan S, Ahmad M, Al-wabel N, Husain A, Ahmad A, Khan SA. Design and synthesis of benzimidazoles containing substituted oxadiazole, thiadiazole and triazolo-thiadiazines as a source of new anticancer agents. Arabian J Chem 2015; doi.org/10.1016/j.arabjc.2015.08.019.

4. Yonova IM, Osborne CA, Morrissette NS, Jarvo ER. Diaryl and heteroaryl sulfides: Synthesis via sulfenyl chlorides and evaluation as selective anti-breast-cancer agents. J Org Chem 2014; 79: 1947-1953.

5. Valente $S$, Trisciuoglio D, Luca TD, Nebbioso A, Labella $D$, Lenoci A, Bigogno C, Dondio G, Miceli M, Brosch G, et al., 1,3,4-Oxadiazole-containing histone deacetylase inhibitors anticancer activities in cancer cells. $J$ Med Chem 2014; 57: 6259-6265.

6. Kumar BNP, Mohana KN, Mallesha $L$, Veeresh $B$. Synthesis and in vitro antiproliferative activity of 2,5disubstituted-1,3,4-oxadiazoles containing trifluoromethyl benzenesulfonamide moiety. Med Chem Res 2014; 23: 3363-3373.

Trop J Pharm Res, March 2017; 16(3): 731 
7. Zhang $K$, Wang $P$, Xuan L, Fu X, Jing F, Li S, LiU Y, Chen $B$. Synthesis and antitumor activities of novel hybrid molecules containing 1,3,4-oxadiazole and 1,3,4thiadiazole bearing schiff base moiety. Bioorg Med Chem Lett 2014; doi.org/10.1016/j.bmcl.2014.09.086

8. Sun J, Zhu H, Zhong-Ming Yang ZM, Zhu HL. Synthesis, molecular modeling and biological evaluation of 2aminomethyl-5-(quinolin-2-yl)-1,3,4-oxadiazole-2(3H)thione quinolone derivatives as novel anticancer agent. Eur J Med Chem 2013; 60: 23-28.

9. Murty MSR, Rao BR, Katiki MR, Nath LR, Anto RJ. Synthesis of piperazinyl benzothiazole/benzoxazole derivatives coupled with 1,3,4-oxadiazole-2-thiol: novel hybrid heterocycles as anticancer agents. Med Chem Res 2013; 22: 4980-4991.

10. Gurupadaswamy HD, Girish V, Kavitha CV, Raghavan SC, Khanum SA. Synthesis and evaluation of 2,5-di(4aryloylaryloxymethyl)-1,3,4-oxadiazoles as anti-cancer agents. Eur J Med Chem 2013; 63: 536-543.

11. Shamsuzzaman, Siddiqui T, Alam MG, Dar AM. Synthesis, characterization and anticancer studies of new steroidal oxadiazole, pyrrole and pyrazole derivatives. J Saudi Chem Soc 2012; doi.org/10.1016/j.jscs.2012.04.009.

12. Bondock S, Adel S, Etman HA, Badria FA. Synthesis and antitumor evaluation of some new 1,3,4-oxadiazolebased heterocycles. Eur J Med Chem 2012; 48: 192199.

13. Feng CT, Wang LD, Yan YG, LiU J, Li SH. Synthesis and antitumor evaluation of some 1,3,4-oxadiazole-2(3H)thione and 1,2,4-triazole-5(1H)-thione derivatives. Med Chem Res 2012; 21: 315-320.

14. Rashid M, Husain A, Mishra R. Synthesis of benzimidazoles bearing oxadiazole nucleus as anticancer agents. Eur J Med Chem 2012; 54: 855-866.

15. Husain A, Rashid M, Mishra R, Parveen S, Shin DS, Kumar D. Benzimidazole bearing oxadiazole and triazolo-thiadiazoles nucleus, design and synthesis as anticancer agents. Bioorg Med Chem Lett 2012; 22 : 5438-5444.

16. Fadda AA, Abdel-Rahman AAH, El-Sayed WA, Zidan TA, Badria FA. Synthesis of novel 1,3,4-oxadiazole derivatives and their nucleoside analogs with antioxidant and antitumor activities. Chem Heterocycl Compd 2011; 47: 1045-1054.

17. Gudipati R, Anreddy RNR, Manda S. Synthesis, characterization and anticancer activity of certain 3-\{4(5-mercapto-1,3,4-oxadiazole-2-yl)phenylimino\}indolin2-one derivatives. Saudi Pharm J 2011; 19: 153-158.

18. Dash S, Kumar BA, Singh J, Maiti, BC, Maity TK. Synthesis of some novel 3,5-disubstituted 1,3,4oxadiazole derivatives and anticancer activity on EAC animal model. Med Chem Res 2011; 20: 1206-1213.

19. Zhang $X$, Sun MQJ, Zhang Y, Yang Y, Wang XL, Tang J, Zhu H. Synthesis, biological evaluation, and molecular docking studies of 1,3,4-oxadiazole derivatives possessing 1,4-benzodioxan moiety as potential anticancer agents. Bioorg Med Chem 2011; 19; 65186524.

20. Abu-Zaied MA, El-Telbani, EM, Elgemeie, GH, Nawwar GAM. Synthesis and in vitro anti-tumor activity of new oxadiazole thioglycosides. Eur J Med Chem 2011; 46: 229-235.

21. Kumar $D$, Sundaree $S$, Johnson EO, Shah K. An efficient synthesis and biological study of novel indolyl-1,3,4oxadiazoles as potent anticancer agents. Bioorg Med Chem Lett 2009; 19: 4492-4494.

22. Tong $Y$, Bouska JJ, Ellis PA, Johnson EF, Leverson J, Liu $X$, Marcotte $P A$, Olson $A M$, Osterling $D J$, Przytulinska $M$, et al., Synthesis and evaluation of a new generation of orally efficacious benzimidazole-based poly(adp-ribose) polymerase-1 (parp-1) inhibitors as anticancer agents. J Med Chem 2009; 52: 6803-6813.

23. Aboraia AS, Abdel-Rahman HM, Mahfouz NH, EL-Gendy MA. Novel 5-(2-hydroxyphenyl)-3-substituted-2,3dihydro-1,3,4-oxadiazole-2-thione derivatives: Promising anticancer agents. Bioorg Med Chem 2006; 14: 12361246.

24. Kumar AKA, Nair KB, Bodke YD, Ganesh SG, Bhat KG. Design, synthesis, and evaluation of the anticancer properties of a novel series of carboxamides, sulfonamides, ureas, and thioureas derived from 1,2,4oxadiazol-3-ylmethyl-piperazin-1-yl substituted with pyrazolo[1,5-a]pyrimidine derivatives. Monatsh Chem. 2016; DOI 10.1007/s00706-016-1723-9.

25. Miralinaghi $P$, Salimi $M$, Amirhamzeh $A$, Norouzi $M$, Kandelousi HM, Shafiee A, Amini M. Synthesis, molecular docking study, and anticancer activity of triaryl-1,2,4-oxadiazole. Med Chem Res 2013; 22: 4253-4262.

26. Tsygankova IG, Zhenodarova SM. The structure property correlation for estimation and predicting the apoptosisinducing activity of 3,5-diaryl-1,2,4-oxadiazoles, the potential antitumor agents. Russ J Gen Chem 2011; 81: 2320-2327.

27. Kumar D, Patel G, Chavers AK, Chang KH, Shah $K$. Synthesis of novel 1,2,4-oxadiazoles and analogues as potential anticancer agents. Eur J Med Chem 2011; 46: 3085-3092

28. Yang X, Liu G, Li H, Zhang Y, Song D, Li C, Wang R, Liu $B$, Liang $W$, Jing $Y$, et al Novel oxadiazole analogues derived from ethacrynic acid: design, synthesis, and structure-activity relationships in inhibiting the activity of glutathione S-transferase $P 1-1$ and cancer cell proliferation. J Med Chem 2010; 53: 1015-1022.

29. Kemnitzer W, Kuemmerle J, Zhang HZ, Kasibhatla S, Tseng B, Drewe J, Cai SX. Discovery of 3-aryl-5-aryl1,2,4-oxadiazoles as a new series of apoptosis inducers. 2. Identification of more aqueous soluble analogs as potential anticancer agents. Bioorg Med Chem Lett 2009; 19: 4410-4415.

30. Kumar D, Patel G, Johnson EO, Shah K. Synthesis and anticancer activities of novel 3,5-disubstituted-1,2,4oxadiazoles. Bioorg Med Chem Lett 2009; 19: 27392741. 
31. Zhang HZ, Kasibhatla S, Kuemmerle J, Kemnitzer W, Ollis-Mason K, Qiu L, Grundy CC, Tseng B, Drewe J, Cai SX. Discovery and structure activity relationship of 3-aryl-5-aryl-1,2,4-oxadiazoles as a new series of apoptosis inducers and potential anticancer agents. $J$ Med Chem 2005; 48: 5215-5223.
32. Nguyen MT, Hegarty AF, Elguero J. Can 1,2,3Oxadiazole be Stable? Angew Chem 1985; 97(8): 704.

33. Semenov SG, Makarova MV. 1,2,3-Oxadiazole Rings in the Aromatic Compounds: A Quantum-Chemical Investigation. Russ J Gen Chem 2011; 81(7): 15551557. 